\title{
PHUBBING SEBAGAI SEBUAH FENOMENA BUDAYA POP STUDI KASUS PADA MAHASISWA FAKULTAS ILMU SOSIAL ILMU POLITIK UNIVERSITAS ANDALAS
}

\author{
Zolla Surya Pratiwi \\ Jurusan Antropologi, Fakultas Ilmu Sosial dan Ilmu Politik, Universitas Andalas \\ zollasuryapratiwi@gmail.com
}

\begin{abstract}
ABSTRAK
Dewasa ini makin banyak mahasiswa yang sengaja atau tanpa sengaja mengacuhkan rekan bicaranya atau lingkungannya demi fokus dengan smartphonenya. Kini smartphone telah menjadi benda yang sangat diperlukan dan dibutuhkan mahasiswa sebagai penunjang kehidupannya, dan menjadikan smartphone sebagai salah satu pilihan gaya hidup bagi kebanyakan orang khususnya generasi milenial. Tujuan penelitian ini untuk mengetahui apa dan bagaimana perilaku phubbing yang terjadi pada mahasiswa FISIP, alasan melakukan perilaku phubbing serta bagaimana pandangan mereka sebagai pengkaji masalah-masalah sosial terhadap perilaku yang juga mereka lakukan sendiri. Penelitian ini menggunakan metode kualitatif yang bersifat deskriptif, dengan menggunakan teknik pengumpulan data berupa observasi, wawancara, dokumentasi serta studi kepustakaan. Dengan menggunakan beberapa konsep seperti kebudayaan, budaya pop, gaya hidup, interaksi sosial. Temuan dalam penelitian ini ialah mahasiswa FISIP merasa pernah dengan sengaja atau tanpa sengaja dan sadar atau tanpa sadar melakukan perilaku phubbing, namun hanya beberapa dari mereka yang tahu bahwa tindakan yang mereka lakukan tersebut diistilahkan dengan sebutan phubbing. Berbagai hal serta alasan yang membuat mahasiswa FISIP berperilaku phubbing yakni kebiasaan scrooling sosial media, kecanduan game, balasan phubbing akibat diphubbingkan, keasyikan nonton atau membaca novel online, ketidaknyamanan mahasiswa terhadap lingkungan atau bahkan mahasiswa lain yang tidak disukainya dan sebagainya. Phubbing telah menjadi kebiasaan yang sudah membudaya bagi mahasiswa. Sebagian mahasiswa FISIP berpendapat bahwa phubbing sudah lumrah terjadi mengingat zaman yang tengah modern namun tentu juga banyak mahasiswa yang menyayangkan tindakan tersebut. Sebuah ironi jika dengan kemunculan smartphone membuat mahasiswa merasa asing dengan lingkungan sosial sekitarnya, mereka lebih suka berdiam diri dan menikmati dunianya sendiri tanpa mempedulikan lingkungan sosialnya. Kesadaran untuk berkomunikasi di dunia nyata perlu untuk ditingkatkan karena pada hakikatnya orang-orang hidup di dunia nyata, bukan di dunia maya.
\end{abstract}

Key Words: phubbing, fenomena, budaya pop.

\section{PENDAHULUAN}

Teknologi merupakan alat bantu manusia untuk memenuhi kebutuhannya, sehingga teknologi diciptakan untuk memudahkan serta melancarkan pekerjaan manusia. Seiring berkembangnya zaman, teknologi dan informasi dirasakan berkembang secara luar biasa. Alat komunikasi merupakan salah satu dari kemajuan teknologi saat ini. Alat telekomunikasi berkembang dengan pesat, dulu hanya sekadar telepon rumah yang digunakan oleh orang-orang, kemudian lambat laun berkembang dan mulai beralih ke handphone dan sekarang sudah masuk ke era smartphone. Asumsi dasar bahwa komunikasi berhubungan dengan perilaku manusia dan kepuasan terpenuhinya kebutuhan berinteraksi dengan manusia-manusia lainnya, maka setiap orang memerlukan sebuah komunikasi baik itu secara langsung maupun tidak langsung, karena mereka membutuhkan hubungan sosial dengan orang lain dan kebutuhan ini terpenuhi melalui pertukaran pesan yang berfungsi sebagai jembatan untuk mempersatukan manusia-manusia yang tanpa berkomunikasi akan terisolasi (Sihabudin, 2013:14). Sehingga dengan adanya komunikasi manusia bisa berinteraksi dengan manusia lain agar hubungan sosial bisa terbangun guna mempersatukan individu-individu lainnya. 
Cara berkomunikasi antar individu dengan individu lain mengalami perubahan karena adanya alat telekomunikasi seperti handphone maupun smartphone yang mampu mengantarkan pesan-pesan penting yang hendak disampaikan hanya dalam hitungan detik saja. Dengan adanya kemudahan berkomunikasi seperti ini tidak perlu menunggu waktu yang lama untuk dapat berkomunikasi serta bertukar kabar atau kejadian apa saja yang sedang dialami dengan kerabat yang jaraknya sangat jauh sekalipun (Maulidar, 2017:26). Smartphone telah merevolusi cara orang berkomunikasi antara satu dengan yang lainnya, dulu orang jika ingin berkomunikasi harus menemui orang yang dituju atau berkirim surat jika mereka berada di tempat yang berbeda dan jarak yang jauh. Sekarang dengan kemunculan smartphone berapapun jarak yang membentang smartphone bisa menjadi penghantar pesan yang sangat diandalkan. Menurut Turnbull (dalam Youarti \& Hidayah, 2018:144) mengemukakan bahwa seseorang yang banyak menghabiskan waktu untuk mengakses internet, maka dia hanya punya sedikit waktu untuk berkomunikasi dengan orang lain secara nyata. Smartphone memungkinkan orang bisa terhubung dengan orang lain kapan saja dan di mana saja, namun ada kekhawatiran bahwa smartphone bias menjadi pengurang bukan pelengkap dalam hal interaksi sosial individu dengan individu bahkan kelompok.

Badan Survey Internasional menemukan bahwasanya lebih dari setengah mahasiswa dari tiap-tiap Universitas memiliki dan menggunakan smartphone dalam keseharian mereka (Dean dalam Yusrian, 2015:2). Berdasarkan hasil pengamatan penulis, mahasiswa Fakultas Ilmu Sosial Ilmu Politik Universitas Andalas sering duduk bersama-sama tetapi tidak saling berbincang. Rata-rata dari mereka lebih fokus memainkan smartphone daripada membangun pembicaraan dengan mahasiswa lain yang berada di sekitar mereka. Di beberapa tempat seperti di depan corner gedung B, peneliti memperhatikan 4 orang mahasiswa Fakultas Ilmu Sosial Ilmu Politik duduk bersama dengan smartphone di genggamannya, terlihat 3 orang asik memainkan smartphone milik mereka dan teman yang satu lainnya hanya memperhatikan teman-temannya tersebut dengan raut wajah cemberut. Contoh lainnya yang peneliti amati di kelas saat sedang berlangsung perkuliahan banyak mahasiswa yang asik mengoperasikan smartphone-nya dari pada memperhatikan dosen yang sedang menjelaskan materi perkuliahan di depan kelas terkesan materi yang diberikan dosen tidak menarik baginya. Mereka lebih memilih berinteraksi dengan smartphone-nya dibandingkan berinteraksi dengan lingkungan sekitar mereka. Hal ini menunjukkan kurangnya kepedulian dan sikap saling menghargai mahasiswa terhadap lingkungan sosial yang ada di sekitarnya.

Banyak mahasiswa menggunakan smartphone untuk bermain game, bersosial media, berbelanja online, mendengarkan musik, meng-update informasi dan berita agar mahasiswa tidak terbatas mendapatkan informasi-informasi hanya dari dosen dan dalam ruangan perkuliahan saja atau hanya sekadar tuntutan lingkungan (trend) agar tidak ketinggalan dari teman-temannya, atau mereka merasa malu memiliki handphone yang hanya bisa digunakan untuk sebatas melakukan panggilan telepon dan pesan singkat saja (Yusriani, 2015:3). Bahkan banyak mahasiswa yang beranggapan bahwa canggih atau tidak canggihnya sebuah smartphone yang dimilikinya sebagai tolak ukur penentu kelas sosial apakah mahasiswa tersebut termasuk level yang gaul dan kekinian atau level yang biasa saja di lingkungan mahasiswa kebanyakan. 
Smartphone dilengkapi akses internet dan dapat dibawa ke mana saja. Seseorang bahkan merasa menggenggam dunia ketika smartphone tersebut ada di tangannya. Kehadiran internet kini mulai mengaburkan defenisi media tradisional seperti media cetak hingga radio dan televisi yang tidak lagi dibatasi oleh geografis, perbedaan demografis, bahkan psikografis (Nasrullah, 2012:24). Bahkan di era sekarang dengan bermodalkan sebuah smartphone saja seseorang bias mendengarkan radio bahkan menonton tayangan yang biasanya ada di televisi dengan bantuan sebuah internet. Menurut Holmes, internet merupakan tonggak dari pesatnya perkembangan teknologi interaksi global yang mengubah cakupan serta sifat dasar dari komunikasi (Nasrullah, 2012:61). Sejalan dengan itu internet menjadi bagian paling penting dari perkembangan teknologi terkhusus pada smartphone, karena dengan internet sebuah smartphone bisa beroperasi dengan baik sesuai dengan beragamnya kebutuhan dan keinginan orang-orang terhadap smartphone guna mempermudah kehidupannya.

Kecanggihan yang dimiliki oleh smartphone secara langsung maupun tidak langsung turut mengubah gaya hidup penggunanya. Gaya hidup mereka terlihat dari keperluan mereka menggunakan smartphone-nya (Yusriani, 2015:3). Mahasiswa FISIP misalnya, mereka menggunakan smartphone sebagai penunjang dalam perkuliahan, dulu mahasiswa ke kampus membawa dan membutuhkan buku-buku pelajaran yang relevan dengan materi perkuliahan ataupun buku tulis untuk mencatat materi perkuliahan, tapi sekarang mahasiswa tidak perlu repot lagi harus mencari buku-buku di perpustakaan karena mereka dapat mengakses materi perkuliahan melalui internet dan memotret materi yang ditulis atau ditampilkan lewat slide oleh dosennya. Harga smartphone terbilang cukup terjangkau, sehingga smartphone menjadi barang yang dapat dimiliki oleh seluruh kalangan. Segala aktivitas pasti berhubungan dengan smartphone (perangkat elektronik canggih), termasuk permainan anak- anak, bahkan sejak balita anak-anak sudah dikenalkan dengan smartphone, karena orangtua menggunakan smartphone sebagai media untuk mengasuh anak ketika mereka sedang sibuk bekerja (Utami, 2013). Dengan berbagai kemudahan yang disuguhkan smartphone membuat banyak orang ketergantungan karena segala aktivitas bisa diselesaikan dengan cepat dan lebih efisien.

Di sisi lain membuat orang-orang lupa akan dampak negatif yang ditimbulkannya, seperti sikap acuh si pengguna terhadap lingkungan di sekitarnya, si pengguna menjadi kurang memiliki kepedulian terhadap lingkungan sekitar karena lebih fokus terhadap smartphone yang ada di genggaman nya. Jika di dalam sebuah rumah, seluruh anggota keluarganya memiliki smartphone mulai dari orang tua (ayah dan ibu), anak (adik dan kakak), maka dapat dipastikan komunikasi di dalam rumah tersebut akan sedikit terganggu. Masing-masing anggota keluarga akan asyik dengan smartphone-nya masing- masing. Sang adik asyik dengan game-nya, sang kakak asyik dengan obrolan sosialitanya, ibu bergosip dengan teman-teman arisannya, bapak asyik dengan urusan bisnis kantornya. Itulah salah satu fenomena yang terjadi sekarang ini (Wilantika, 2015:16). Tetapi kalau dibandingkan dengan keadaan di mana sebelum anggota keluarga tersebut memiliki dan terlalu fokus terhadap smartphone, maka komunikasi di dalam keluarga tersebut bisa terbangun dengan baik, mereka hanya akan fokus dengan komunikasi nyata yang terjadi antar anggota keluarga, seperti sang adik akan belajar bersama dengan sang kakak, sang ibu dan ayah bisa berdiskusi mengenai perkembangan anak-anaknya, sehingga komunikasi terbangun dengan baik dan dapat mengurangi 
serta menghindari sifat-sifat anti sosial yang dapat membuat seseorang tidak peduli dengan lingkungan sekitarnya dan bisa saling menghargai antar individu di lingkungan sosial yang ada di sekitarnya.

Pada saat sekarang ini kita bisa menemukan fenomena seseorang memainkan smartphone tanpa memedulikan lingkungan sekitar. Fenomena-fenomena tersebut bisa kita temui di beberapa tempat di Kota Padang, misalnya di tempat makan, yang sebelumnya mereka mengajak bertemu untuk quality time di cafe karena sudah jarang bertemu, malah sesampai di cafe yang mengajak bertemu malah asyik menggunakan wifi cafe untuk mengoperasikan smartphone-nya. Alhasil yang diajak tadi malah teracuhkan, contoh berikutnya dapat diperhatikan saat di kampus, saat sedang mengikuti sebuah rapat angkatan, bukannya mendengarkan materi rapat tersebut tetapi malahan banyak yang asyik dengan smartphone-nya, berselfie, bersosial media, alhasil saat ditanya apa inti dan tujuan dari rapat tersebut mereka tidak dapat menjawab karena tidak mendengarkan rapat dengan baik dan ketua rapat pun merasa kecewa karena teracuhkan dan terabaikan, contoh lainnya di jalanan umum, mereka berjalan bergandengan yang satu sibuk bercerita masalahnya yang satu sibuk menatap smartphone-nya, saat ditanya bagaimana pendapatnya kepada temannya, temannya malah tidak nyambung karena tidak mendengarkan dengan baik dan yang bercerita merasa sedih, kesal dan kecewa karena ia beranggapan bahwa dirinya tidak dipedulikan dan dihiraukan.

Fenomena ini bisa saja terjadi pada siapapun, misalnya saat dua orang atau lebih berada dalam satu tempat yang sama, namun mereka saling berinteraksi dengan smartphone yang ada di genggamannya masing-masing sehingga lingkungan sosialnya merasa teracuhkan dan terabaikan. Griffiths mengemukakan bahwa apabila seseorang mengalami kecanduan maka orang tersebut akan lupa waktu, hingga ia tidak menghiraukan keadaan sekitar dan tidak menghargai orang di sekitarnya (Youarti \& Hidayah, 2018:146). Banyak orang menjadi acuh dan kehilangan banyak waktu karena terlalu sibuk memainkan smartphone-nya, misalnya keasikan bermain game sampai lupa waktu salat, belajar, makan bahkan mengacuhkan dan tidak mendengarkan perintah orang tua. Sehingga perilaku phubbing muncul dan menjadi dampak akibat penggunanya tidak mampu lagi memanfaatkan teknologi yang ada dengan bijak dan semestinya.

Fenomena phubbing merupakan singkatan yang berasal dari kata "phone" yang berarti telepon dan "snubbing" yang berarti mengabaikan, menyakiti atau menyepelekan dengan tidak menghiraukan atau tidak mengacuhkan kehadiran orang lain. Kehadiran fenomena phubbing lahir karena besarnya ketergantungan individu terhadap smartphone dan internet (Hanika, 2015:42). Taufik Hidayat Kepala Bidang Layanan e-Goverment Dinas Komunikasi, Informasi dan Statistik (Diskominfo) mengatakan istilah phubbing mulai booming bersamaan dengan maraknya smartphone yang tidak sekadar untuk telepon dan SMS tetapi juga mempunyai banyak aplikasi seperti game, jejaring sosial yang membuat orang betah berlama-lama memegang smartphone. Karena begitu banyaknya perilaku orang-orang sibuk sendiri sehingga tidak mempedulikan lawan bicara atau orang-orang di sekitarnya akibat fokus mengoperasikan smartphone, akhirnya pada Mei 2012 sejumlah ahli pakar bahasa, budayawan, sosiolog, phonetik, penyair,dan sebagainya berkumpul di Sydney University, bersama organisasi bernama Macquaire Dictionary untuk merumuskan sebuah istilah yang menggambarkan perilaku tersebut sehingga melahirkan kata phubbing. 
Fenomena phubbing dianggap sebagai sesuatu hal yang negatif karena manusia cenderung menyepelekan lawan bicara dan tidak memberikan apresiasi (Hanika, 2015:47). Mahasiswa secara sadar atau tidak sadar saat berinteraksi sembari mengoperasikan smartphone mereka seringkali membuat lawan bicaranya tersepelekan akibat terlalu fokus dengan smartphone-nya, sehingga membuat lawan bicaranya menduga-duga, mengira dan merasa bahwa kehadirannya tidak penting dan tidak diinginkan saat itu. Kecenderungan seseorang menyepelekan, mengabaikan, meremehkan seseorang demi fokus ke smartphone-nya membuat lawan bicaranya merasa terhina karena lebih mementingkan smartphone-nya ketimbang membangun pembicaraan dengan rekan bicaranya.

Istilah phubbing menggambarkan tindakan penghinaan terhadap seseorang dalam lingkungan sosial dengan terus memperhatikan ponsel, bukan berbicara dengan orang tersebut secara langsung (Haigh dalam Ridho, 2019:19). Orang-orang akan merasa terhina dan tersakiti jika lawan bicaranya mencuekkannya hanya demi memainkan smartphone, ia akan merasa tidak dihargai. Bagaimana tidak setiap orang tentunya ingin dihargai dan acuhkan ketika sedang berada di lingkungan sosialnya. Seseorang dapat dikatakan sebagai phubber atau orang yang melakukan phubbing apabila ia menyakiti lawan bicaranya dengan terlalu mengacuhkan smartphone-nya dan lebih fokus pada smartphone daripada lawan bicaranya dalam lingkungan sosialnya. Seseorang dapat dikatakan sebagai phubbee apabila ia menjadi korban atau orang yang merasa tersakiti, terhina apabila lawan bicaranya lebih fokus dengan smartphone-nya dibandingkan dirinya. Mahasiswa yang berperilaku phubbing bahkan dengan sengaja mencari kesibukan lain demi menghindari orang atau lingkungan yang tidak ia senangi dan terkesan acuh.

Pelaku phubbing merasa bahwa ia tetap menjalankan interaksinya dengan orang lain tetapi diperantarai oleh smartphone. Ia bahkan bisa menjalin interaksi dengan orang yang berada jauh darinya, tetapi ia tidak sadar bahwa interaksinya dengan lingkungan social di mana ia berada menjadi tidak terjalin dengan baik karena ia lebih sibuk dengan dunia maya di smartphonenya. Tidak dapat kita pungkiri bahwa untuk berbicara dengan orang lain tanpa memainkan smartphone menjadi hal yang sulit untuk kebanyakan orang, bahkan orang-orang lebih memilih berdiam diri di dalam kamar sembari memainkan smartphone-nya daripada menjalin hubungan sosial dengan lingkungannya di luaran sana. Mereka menganggap bahwa dengan smartphone saja ia bisa menjangkau informasi berdasarkan update status dari orang-orang, sehingga ia tidak perlu capek-capek harus ke luar rumah untuk mendapatkan informasi lagi.

Perilaku phubbing dapat mengancam terganggunya hubungan dalam keluarga, pertemanan, persahabatan dan juga perilaku phubbing yang mengabaikan dan tidak memedulikan orang lain ini akan mengancam ketidakpercayaan orang terhadapnya (Akbar, 2018). Orang yang sering berperilaku phubbing sering mendapat teguran dari orang-orang yang berada di lingkungannya, sesaat ditegur memang ia akan menghentikan fokusnya dari smartphone tetapi selang beberapa saat ia kembali melakukan perilaku tersebut, sehingga membuat sang phubbee berfikir bahwa ia tidak penting, dan tidak ada harganya karena sering diabaikan sehingga karena itu sang phubbee menjadi was-was dan nenaruh ketidakpercayaan setiap bersama dengan orang yang sering mengacuhkannya tersebut. Peneliti Varoth Chotpitayasunondh dan Karen Douglas dari Sekolah Psikologi Kent percaya bahwa phubbing dapat sangat merusak rasa memiliki, harga diri serta keberadaan yang bermakna, karena pada dasarnya tidak ada orang yang senang diabaikan dan tidak diacuhkan (Nisa 
\& Rahmawati, 2018). Orang yang tergolong ke dalam perilaku phubbing sekalipun tidak akan menyukai jika orang-orang di sekitarnya mengabaikan dan tidak mengacuhkannya. Seharusnya jika seseorang ingin di acuhkan dan dihargai, orang tersebut juga harus mengacuhkan dan menghargai orang lain karena bisa jadi orang-orang yang tidak menghargai kita berperilaku demikian karena kita tidak menghargainnya pula.

Kemunculan istilah "no mobile phone phobia"sebagai akibat dari ketergantungan pada smartphone di mana seseorang tidak bisa jauh dari smartphone-nya dan smartphone menjadi andalan manusia di situasi apapun di zaman modern sekarang ini. Sehingga keberadaan smartphone saat ini menjadi suatu fenomena yang dapat merusak suatu hubungan karena penggunaan berlebihan. Smartphone memang tidak dapat mempengaruhi orang untuk mengubah sikap, tetapi cukup berpengaruh terhadap apa yang dipikirkan orang, artinya ia mempengaruhi persepsi orang tentang apa yang dianggap penting, jika suatu media selalu memuat nama seseorang, maka orang itu cenderung dianggap tokoh yang penting, jika suatu media menampilkan adegan kekerasan, maka orang-orang akan menganggap dunia ini penuh dengan tindakan-tindakan kejahatan (Rakhmat, 2005:200). Orang-orang cenderung berspekulasi dan beranggapan sesuai dengan apa yang mereka lihat dan dengar saja tanpa membuktikan sebelumnya baik itu terjadi di dunia nyata atau media massa.

Melihat maraknya penggunaan smartphone di kalangan mahasiswa menyebabkan marak pula perilaku phubbing yang diakibatkannya, sehingga sedikit banyaknya mempengaruhi tingkah laku dan gaya hidup mahasiswa, gaya hidup seakan menyesuaikan dengan trend yang ada. Jangan ada gadged di antara percakapan kita, karena ada ibu yang berharap keluhnya didengarkan, ada ayah yang menanti peluhnya dihargai, ada anak yang merindu waktunya dibersamai, ada teman dan sahabat yang berharap ceritanya dipedulikan walau hanya dengan memperhatikan dan menyimak tanpa kita terlalu fokus pada smartphone, karena untuk sekarang ini merasakan sensasi ngobrol asyik tanpa gadget sudah sulit sekali ditemukan. Smartphone telah sukses menggantikan surat, kamera, senter, alarm, kalender, radio, jam dan lain- lain tetapi jangan biarkan benda tersebut juga menggantikan teman, sahabat, keluarga yang ada di sekitar kita.

Peneliti melakukan penelitian mengenai fenomena phubbing di kalangan mahasiswa karena peneliti berasumsi bahwa perilaku phubbing lebih berpotensi terjadi pada generasi millenial yang lahir kisaran 1982-2002 dan mahasiswa cocok dijadikan objek penelitian karena dapat dikategorikan sebagai generasi millenial yang mana generasi tersebut sangat akrab dengan gadget. Perilaku phubbing memang tidak terjadi hanya di kalangan mahasiswa saja atau FISIP saja namun terjadi di semua kalangan yang kurang mengontrol pemakaian smartphonenya, selain FISIP ruang lingkup sosialnya lebih jelas, mahasiswanya beragam jurusan tentu beragam pula gaya hidup, tingkah laku, prioritas serta cara bersosialnya sehingga akan muncul beragam tuturan yang diungkapkannya mengenai pengetahuan, alasan serta pandangannya terhadap perilaku yang dilakukannya tersebut. Sebagaimana kondisi yang terjadi di atas, maka peneliti tertarik untuk melakukan penelitian terkait fenomena phubbing yang terjadi khususnya di kalangan mahasiswa, serta alasan dan pandangan terhadap fenomena tersebut. Yang dikaji dalam riset ini bukanlah smartphonenya namun bagaimana perilaku yang dihasilkan oleh smartphone dan bagaimana perilaku orang terhadap smartphone tersebut. Riset ini penting untuk dikaji dari sudut pandang 
ilmu antropologi yang mana ilmu antropologi tersebut lingkup tujuannya mempelajari manusia, kebudayaan serta perilakunya sehingga cocok antara ruang lingkup dan kajiannya. Penelitian ini dilakukan supaya peneliti bisa memberikan gambaran perilaku seperti apa yang dapat membuat seseorang dikatakan phubber dan penelitian ini perlu dipelajari supaya pembaca dapat mengetahui gambaran dari perilaku phubbing itu sendiri. Penelitian ini sangat berguna bagi semua kalangan agar mereka tahu dan mengerti bagaimana fenomena yang sedang marak saat ini. Setelah mereka mengetahui mereka bisa mulai antisipasi, mengurangi bahkan menghindari perilaku tersebut.

\section{METODE}

Metode penelitian yang digunakan dalam penelitian ini yaitu metode kualitatif yang bersifat deskriptif bertujuan untuk mengidentifikasi, menganalisis dan menginterpretasikan fenomena phubbing serta mendapatkan secara detail pendeskripsian mengenai fenomena phubbing tersebut sehingga pendekatan yang bersifat deskriptif digunakan untuk menggambarkan secara menyeluruh mengenai fenomena phubbing yang terjadi di kalangan mahasiswa FISIP Universitas Andalas.

Teknik pemilihan informan yang digunakan dalam penelitian ini adalah purposive sampling. Ditetapkan kriterianya seperti mahasiswa FISIP, memiliki smartphone, cenderung lebih fokus dengan smartphone daripada rekan bicara, smartphone tidak pernah jauh dari jangkauannya atau dengan kata lain smartphone selalu di tangannya kapanpun dan dimanapun, sering memakai earphone saat bersama dengan lingkungan sosialnya, alasannya karena menurut peneliti orang tersebut memang sengaja menutup diri untuk berinteraksi dengan yang lain. Dalam melakukan penelitian ini ada 4 teknik yang digunakan yakni observasi, wawancara, dokumentasi dan studi kepustakaan.

\section{HASIL DAN PEMBAHASAN}

\section{A. PHUBBING}

Phubbing merupakan suatu tindakan menyakiti orang lain dengan cara mengacuhkannya dan lebih berfokus berinteraksi dengan smartphone daripada lingkungan sosial. Orang yang teracuhkan tersebut merasa terhina karena kehadiran dan keberadaannya saat itu dikalahkan oleh sebuah benda yaitu smartphone. Bagi mahasiswa Fakultas Ilmu Sosial Ilmu Politik beberapa ada yang mengenali sebutan phubbing tersebut namun rata-rata dari mereka hanya mengetahui dan merasakan bahwasanya kebanyakan dari mereka pernah dan sering melakukan tindakan tersebut. Mereka paham dengan maksud dari tindakan tersebut tapi kurang fasih dengan sebutannya. Mereka juga paham dan mengerti bahwa faktanya sekarang ini banyak orang khususnya mahasiswa yang lebih senang dengan smartphonenya dan mengacuhkan orang lain demi bisa selalu bermain dan mengakses smartphone.

Bagi mahasiswa FISIP yang mengenali istilah phubbing, mereka mengartikan bahwa phubbing sebagai suatu bentuk penghinaan terhadap mereka. Perilaku phubbing muncul sebagai bentuk ketidak-pandaian seseorang mengontrol pemakaian smartphonenya, sehingga pemakaian smartphone dalam sehari melampaui batas normal sehingga menjadi suatu kebiasaan untuk sering mencek notifikasi media-media di smartphone. Pentingnya kontrol dan batasan penggunaan serta pengertian dari rekan sesama seperkumpulan atau seperdudukan. Jika keduanya berjalan dengan 
baik mungkin fenomena phubbing tidak terjadi semarak sekarang ini. Tidak ada orang yang akan mengatakan kalau kita berperilaku phubbing jika penggunaan smartphone di batas wajar dan mampu saling menghargai privasi dan saling pengertian antar keduanya.

\section{B. PANDANGAN MAHASISWA FISIP UNAND TERHADAP PERILAKU PHUBBING}

\section{Pandangan Phubber Terhadap Perilaku Phubbing}

Bagi seorang phubber, smartphone adalah segalanya, karena smartphone bisa menjadi teman yang selalu menemani phubber dalam melakukan kesehariannya, dalam keadaan apapun smartphone paling dibutuhkan oleh seorang phubber dibandingkan dengan benda apapun itu.

Bagi phubber, perilaku phubbing sudah hal lumrah yang terjadi di era sekarang yang serba menggunakan dan membutuhkan teknologi. Sudah menjadi hal yang biasa terjadi tetapi tidak disadari kebanyakan orang. Kadang tanpa sengaja phubber melakukan hal tersebut karena ada hal yang sangat penting dan mendesak yang harus ia selesaikan lewat smartphone sehingga membuat ia tidak fokus dengan lingkungannya saat itu. Phubber tidak menyayangkan perilaku dari phubber karena baginya tidak mungkin bisa kita memaksa seseorang untuk berperilaku sesuai yang kita inginkan, karena mereka juga memiliki hak berperilaku sesuai dengan keinginan dan kenyamanannya. Perilaku phubbing sah-sah saja, karena saat ini smartphone bisa menjadi pengembali mood yang hancur, ketika seseorang dilanda kesedihan rata-rata mereka lebih memilih memainkan smartphone dengan berselancar di sosial media untuk mencari konten yang bisa menghibur kesedihannya.

\section{Pandangan Phubbee Terhadap Perilaku Phubbing}

Hal yang dirasakan oleh seseorang ketika ia menjadi korban dari perilaku phubbing yaitu kesal, sebal, sedih, marah, kecewa, merasa tidak penting, seorang phubbee akan bertanya-tanya kenapa ia seringkali di acuhkan dan diabaikan. Seseorang yang merasa diabaikan dan diacuhkan karena rekan bicaranya lebih asik dengan smartphone ia akan merasa tersakiti karena keberadaannya kalah saing dengan smartphone.

Seorang phubbee memandang perilaku phubbing sebagai suatu bentuk tindakan yang meresahkan bagi dirinya, perilaku phubbing bahkan bisa mengancam keharmonisan dalam sebuah hubungan pertemanan. Bayangkan saja ketika sedang berkumpul bersama teman-teman dengan tujuan untuk melepas rasa rindu, tetapi dengan perilaku phubbing tersebut malah mengubur ekspektasi tadi, malahan sibuk dengan urusan smartphonenya masing-masing. Perilaku phubbing bisa sangat mengganggu ketika suasana hati sedang tidak karuan atau sedang tidak mood. Bahkan perilaku phubbing tersebut juga bisa menjadi alasan seseorang menjadi tidak mood.

\section{Pandangan Phubbee Terhadap Phubber}

Kadang phubbee juga tidak ingin menampakkan raut wajah kekesalan kepada phubber karena merasa tidak enak jika nantinya terjadi salah paham dan untuk sekedar menegur phubber juga tidak berani dilakukan oleh phubbee, karena baginya jika ia melakukan hal tersebut nantinya malah merusak hubungan yang telah terbangun. 
Bagi phubbee, ia memandang phubber sebagai orang yang kurang menghargai lingkungan sekitarnya dan kurang sopan, karena baginya ketika ia tengah berbicara tetapi phubber malah asyik dengan smartphonenya itu sebagai suatu bentuk sikap yang kurang sopan dan tidak menghargai orang lain. Bagi phubbee yang sering merasa teracuhkan dan tercueki oleh phubber kadang lebih memilih untuk menghindari bertemu dengan phubber ketika berada di tempat yang sama, phubbee menjadi malas untuk sekedar bertemu dengan phubber karena pengalaman yang dilaluinya cukup berbekas.

\section{ALASAN PHUBBER CENDERUNG MELAKUKAN PERILAKU PHUBBING}

\section{Kebiasaan mengakses sosial media}

Kebiasaan menggunakan, memainkan dan mengoperasikan smartphone untuk mengakses sosial media membuat banyak orang menjadi terpaku menatap layar smartphonenya untuk sekedar scrolling konten yang tak pernah ada habisnya.

Kebiasaan kita mendapatkan kepuasan dan kesenangan yang instan lewat sosial media akan tertanam di diri kita sebagai makhluk sosial. Ini akan membuat kita menjadi malas, tidak memiliki kesabaran dan hanya ingin yang serba instan, malas bekerja keras, malas bersosial dan berinteraksi dengan dunia nyata. Karena yang ada di pikirannya untuk apa melakukan semua itu untuk mendapatkan kepuasan kalau hanya dengan berdiam diri di rumah dan browsing sosial media juga mendapatkan kepuasan dan kebahagiaan yang sama.

\section{Kecanduan mengakses dan memainkan game online}

Karena menggunakan dan mengoperasikan aplikasi-aplikasi yang ada di smartphone telah menjadi suatu kebiasaan, yang selalu dimainkan, diotak-atik, diakses dan digunakan, sehingga lambat laun orang tersebut menjadi kecanduan terhadapnya, akibatnya ia tidak tenang kalau smartphone tidak ada di dekatnya dan ia tidak tenang jika ia tidak memainkan, menggunakan dan mengoperasikan smartphone tersebut walau sekedar untuk gaming.

\section{Ketergantungan untuk selalu mengakses aplikasi-aplikasi yang terdapat di dalam Smartphone}

Ketika memainkan dan mengoperasikan aplikasi-aplikasi yang terdapat di smartphone telah menjadi kebiasaan seseorang, lalu orang tersebut menjadi kecanduan dibuatnya dan pada akhirnya akan membuat orang yang bersangkutan menjadi ketergantungan terhadap smartphone. Ia selalu mengandalkan dan memanfaatkan smartphone untuk memenuhi segala kebutuhannya, mulai dari pekerjaannya menggunakan layanan browser, kemudian makan menggunakan layanan online, berbelanja online, sampai berkenalan dan berteman online menggunakan aplikasi yang ada di smartphone. membuat orang- orang malas untuk melakukan pekerjaan dan memenuhi kebutuhannya sendiri, karena dengan modal smartphone saja kebutuhannya bisa terpenuhi tanpa harus ia yang melakukannya. Sehingga ia selalu membutuhkan smartphone dari pada orang-orang di sekitarnya. 


\section{PENUTUP}

Mahasiswa Fakultas Ilmu Sosial Ilmu Politik secara sadar atau tidak sadar dan sengaja atau tidak sengaja pernah melakukan (phubber) atau menjadi korban (phubbee) dari tindakan tersebut. Rata-rata mahasiswa FISIP hanya mengetahui dan merasakan bahwasanya kebanyakan dari mereka pernah dan sering melakukan tindakan tersebut. Mereka paham dengan maksud dari tindakan tersebut tapi kurang fasih dengan sebutannya. Menurut mahasiswa FISIP mahasiswa yang phubbing ialah mereka yang lebih sering asyik bermain dan mengutak- atik smartphonenya dari pada mengacuhkan temannya berbicara kepadanya. Bagi mahasiswa FISIP yang paham betul dengan phubbing ia mengartikan tindakan tersebut sebagai suatu bentuk penghinaan terhadap mereka dan dianggap mengganggu. Sedangkan mahasiswa lain yang tidak terlalu ambil pusing dengan tindakan tersebut mereka menganggapnya biasa saja bahkan menerima dan memakluminya karena perkembangan zaman yang telah modern seperti sekarang ini.

Orang yang cenderung melakukan perilaku phubbing dilatarbelakangi oleh beberapa hal, seperti kebiasaan menakses sosial media, adanya tuntutan untuk selalu berkabar dan dikabari oleh pasangan, tuntutan pekerjaan online, gaming, berada di luar zona nyaman, mengikuti hobi seperti membaca komik online, novel online atau meninton drama Korea di smartphone, dan balas dendam atau phubbing karena diphubbingkan oleh phubber. Semua hal tersebut bias menjadi dasar seseorang terpaku dengan smartphonenya dan enggan berinteraksi langsung dengan temantemannya, yang membuat orang terpaku tentu aplikasi di dalam smartphone tersebut, karena selalu diakses setiap harinya sehingga menjadi kebiasaan lambat laun membuat orang kecanduan untuk memainkannya bahkan menjadikan seseorang ketergantungan dengan smartphone karena aplikasi atau konten di dalamnya. Sehingga membuat orang betah berlama-lama menatap layar smartphone tersebut.

Pandangan mahasiswa FISIP terhadap perilaku phubbing, rata-rata mahasiswa FISIP yang dikategorikan phubber memaklumi adanya perilaku phubbing, mengingat perkembangan zaman dan sekarang serba mengandalkan teknologi, yang mana semua hal bisa dilakukan hanya dengan satu klik, sehingga tak heran jika saat sekarang orang lebih akrab dengan smartphonenya. Sedangkan mahasiswa yang menjadi dikategorikan phubbee memandang perilaku phubbing sebagai suatu bentuk tindakan yang meresahkan, menghina, sekaligus melecehkan baginya, karena tidak ada orang yang senang diacuhkan apalagi hanya karena sebuah smartphone. Dan phubbee memandang phubber sebagai penghancur suasana, penghancur mood dan kerap dihindari ketika bertemu atau berpapasan dengan phubber.

\section{DAFTAR PUSTAKA}

1993. Antropologi Edisi Empat Jilid 2. Jakarta: Erlangga.

Adlin, Alfathri (ed). 2015. Resistensi Gaya Hidup: Teori Dan Realitas. Yogjakarta: Pustaka Pelajar. Afrizal, 2014. Metode Penelitian Kualitatif. Jakarta: PT RajaGrafindo Persada.

Arifin, Zainal. 2013. Pedoman Penulisan Proposal Penelitian Skripsi dan Buku Konsultasi. Padang. 
Azizi, Abdul. 2019. "No Mobile Phone Phobia di Kalangan Mahasiswa Pascasarjana” dalam Jurnal Bimbingan dan Konseling, Vol 6 No 1, Hal 1-10.

Barker, Chris. 2008. Cultural Studies Teori Dan Praktik. Bantul: Kreasi Wacana.

Chaney, David. 2017. Lifesyles: Sebuah Pengantar Komprehensif. Yogjakarta: Jalasutra.

Creswell, John. W. 2014. Penelitian Kualitatif \& Desain Riset. Yogyakarta: Jalasutra.

Daulay, Maraimbang. 2010. Filsafat Fenomenologi: Suatu Pengantar. Medan: Panjiaswara Press.

Effendi, Sofian \& Tukiran. 2012. Metode Penelitian Survei. Jakarta: LP3ES.

Hall, Stuart dkk. 2011. Budaya Media Bahasa: Teks Utama Pencanang Cultural Studies 19721979. Yogyakarta: Jalasutra.

Hanika, Ita Musfirowati. 2015. "Fenomena Phubbing Di Era Milenial: Ketergantungan Seseorang Pada Smartphone Terhadap Lingkungannya” dalam Jurnal Interaksi, Vol. 4, No. 1, Hal. 42-51.

Hartono, Hendri. 2015. "Fenomena Aplikasi Pengolah Foto Digital Pada Ponsel Pintar di Masyarakat Kota" dalam jurnal humainora, Vol.6, No.1, Hal 59-66.

Hasan, S. Suwardi. 2017. Pengantar Cultural Studies: Sejarah, Pendekatan Konseptual, \& Isu Menuju Studi Budaya Kapitalisme Lanjut. Jogjakarta: Ar-Ruzz Media.

Haviland, A. William. 1999. Antropologi Edisi Empat Jilid 1. Jakarta: Erlangga.

Helmi, Azkia. 2017. “ Penggunaan Handphone di Kalangan Siswa SMP di Jorong Taratak Baru Kenagarian Salimpat Kecamatan Lembah Gumanti Kabupaten Solok”. Padang: Skripsi, Jurusan Antropologi Sosial Universitas Andalas.

KBBI. 2018. Kamus Besar Bahasa Indonesia Pusat Bahasa Edisi Keempat. Jakarta: PT Gramedia Utama.

Khairi, Nisa Ul. 2018. "Pola Komunikasi Keluarga Dalam Pembentukan Interaksi Anak: Ketergantungan Penggunaan Smartphone Pada Anak”. Padang: Thesis, Jurusan Ilmu Komunikasi Universitas Andalas.

Mardalis, 2014. Metode Penelitian Suatu Pendekatan Proposal. Jakarta: Bumi Aksara.

Maulidar, Sri.2017. "Pengaruh Penggunaan Smartphone Dalam Gaya Hidup Modern Terhadap Komunikasi Interpersonal Kalangan Pemuda di Kecamatan Syiah Kuala Banda Aceh" dalam Jurnal Ilmiah Mahasiswa FISIP Unsyiah, Vol.2, No. 4, Hal. 24-34.

Nasrullah, Rulli. 2012. Komunikasi Antarbudaya di Era Budaya Siber. Jakarta: Kencana Prenadamedia Group.

Rakhmat, Jalaludding. 2005. Psikologi Komunikasi. Bandung: PT Remaja Rosdakarya.

Ridho, Muhammad Ali. 2019. "Interaksi Sosial Pelaku Phubbing”. Surabaya: Skripsi, Jurusan Psikologi Universitas Islam Negeri Sunan Ampel.

Sihabudin, Ahmad. 2013. Komunikasi Antar Budaya Satu Perspektif Multidimensi. Jakarta: Bumi Aksara. 
Soekanto, Soerjono. 2012. Sosiologi Suatu Pengantar. Jakarta. Rajawali Pers. Sugiyono, 2009. Metode Penelitian Kuantitatif Kualitatif dan R\&D. Bandung: Alfabeta.

Soekanto, Suryono. 1997. Sosiologi Suatu Pengantar. Jakarta. PT. Raja Grafindo Persada.

Sugiyono, 2010. Statistika Untuk Penelitian. Bandung: Alfabeta.

Suparlan, Parsudi. 1993. Kemiskinan di Perkotaan. Jakarta: Yayasan Obor Indonesia.

Wilantika Cancan Firman. 2015. "Pengaruh Penggunaan Smartphone Terhadap Kesehatan Dan Perilaku Remaja” dalam Jurnal Obstretika Scienta, Vol. 3, No. 2.

Youarti, Elok Inta \& Nur Hidayah. 2018. "Perilaku Phubbing Sebagai Karakter Remaja Generasi Z” dalam Jurnal Fokus Konseling, Vol. 4, No. 145, Hal. 143-152.

Yusriani. 2015. "Fenomena Gaya Hidup Pengguna Android di Kalangan Mahasiswa Ilmu Komunikasi Unsyiah”. Banda Aceh: Thesis, Jurusan Ilmu Komunikasi Universitas Syiah Kuala.

Zhafira, Talitha. 2018. "Sikap Asosial Pada Remaja Era Millenial” dalam Jurnal Sosietas, Vol. 8, No. 2, Hal. 501-504.

https://lifestyle.kompas.com/read/2013/06/29/1703028/Banyak.Orangtua.Andalkan.Gadget.untuk.M engasuh.Anak: Banyak Orangtua Andalkan Gadget Untuk Mengasuh Anak. (download tanggal 19 Maret 2019).

http://stopphubbing.com: Stop phubbing. (download tanggal 08 April 2019).

https://www.dewiku.com/relationship/2018/08/03/133000/bahaya-phubbing-bisa- mengancamhubungan-sosialmu: Bahaya, Phubbing Bisa Mengancam Hubungan Sosialmu. (download tanggal 25 Maret 2019).

https://fisip.unand.ac.id/en: fisip Universitas Andalas. (download tanggal 20 November 2019).

https://unand.ac.id/id/\#: Universitas Andalas. (download tanggal 20 November 2019).

https://unand.ac.id/id/: Sejarah Ringkas Universitas Andalas. (download pada 20 November 2019, pukul 12.18).

https:/fisip.unand.ac.id/en/: Sejarah FISIPUnand. (download pada 20 November 2019, pukul 12.45).

https://fisip.unand.ac.id/en/: VISI DAN MISI. (download pada 20 November 2019, pukul 12.50).

https:/www.nesabamedia.com: pengertian, manfaat, kekurangan dan kelebihan whatsapp. (download pada 6 februari 2020, pukul 11.57).

https://www.nesabamedia.com: pengertian, fungsi, fitur, kekurangan dan kelebihan line. (download pada 6 februari 2020, pukul 21.34)

https://www.nesabamedia.com: pengertian, sejarah dan manfaat twitter. (download pada 6 februari 2020, pukul 23.10).

https://www.nesabamedia.com: pengertian, sejarah dan manfaat facebook. (download pada 6 februari 2020, pukul 23.30).

https://www.nesabamedia.com: pengertian, sejarah dan fungsi instagram. (download pada 6 februari 2020, pukul 23.40). 
https://www.nesabamedia.com: pengertian, manfaat dan fitur-fitur youtube. (download pada 6 februari 2020, pukul 23.44).

https://www.gojek.com: layanan gojek. (download pada 6 februari 2020, pukul 23.52).

https://www.nesabamedia.com: pengertian, sejarah, keunggulan dan fitur-fitur joox. (download pada 7 februari 2020, pukul 00.04).

https://www.nesabamedia.com: pengertian, fungsi, kelebihan dan kekurangan shareit. (download pada 7 februari 2020, pukul 00.12).

https://www.nesabamedia.com: pengertian, fungsi dan cara kerja email. (download pada 7 februari 2020, pukul 00.18)

https://www.nesabamedia.com: pengertian dan keunggulan shopee. (download pada 7 februari 2020, pukul 00.23).

https://www.abonu.com: kegunaan dan cara pemakaian snapchat. (download pada 7 februari 2020, pukul 00.36).

https://www.kompasiana.com: fenomena pubg dan kenikmatan berimajinasi. ( download pada 7 februari 2020, pukul 21.44).

https://www.salamadian.com: sejarah, perkembangan dan fitur google (download pada 7 februari 2020, pukul 21.52).

https://www.kreativv.com: webtoon komik kekinian favorit milenial. (download pada 7 februari 2020, pukul 22.07).

https://www.kompasiana.com: wattpad aplikasi keren bagi para penulis dan pembaca. (download pada 7 februari 2020, pukul 22.10). 